\title{
EDUCATIONAL VIDEO AS EFFECTIVE COMMUNICATION ON FORMAL AND INFORMAL CAREGIVER TO ELDERLY : A DESCRIPTIVE STUDY
}

\section{Achmad Fajar Putra Nurdiansyah ${ }^{1}$, Syarif Syamsi Ahyandi ${ }^{1}$, Alvian Wahyu Mahesya ${ }^{1}$, Aryunidya Asmaradianti ${ }^{1}$, Avida Marisa Ilmi ${ }^{1}$, Meutia Putri Aristya ${ }^{1}$, Rani Nurvita ${ }^{1}$, Lady Sherly Nuramalia ${ }^{1}$, Kadek Rama Narottama ${ }^{1}$, Nyilo Purnami*2 ${ }^{\mathbb{D}}$, Pudji Lestari ${ }^{3}$}

${ }^{1}$ Faculty of Medicine, Universitas Airlangga, Indonesia ${ }^{2}$ Department of Ear Nose Throat (ENT) - Head Neck Surgery, Faculty of Medicine, Universitas Airlangga - Dr. Soetomo General Academic Hospital, Indonesia ${ }^{3}$ Department of Public Medicine, Faculty of Medicine, Universitas Airlangga - Dr. Soetomo General Academic Hospital, Indonesia

ABSTRACT
Presbycusis is a progressive hearing loss which occurs at the age
of 65. Communication difficulties caused by these problems are
usually not understood or understood by people with normal
hearing functions. Therefore, the understanding of these problems
must be improved so that there is no gap between people with
normal hearing and people with low hearing. The research
method used is a quantitative descriptive research design carried
out in a number of elderly care foundations. The data we share is
in the form of pre-test and post-test questionnaires to elderly
caregivers with hearing loss in order to evaluate the caregiver's
understanding of the educational video. There was an increase in
the understanding of the caregivers about how to communicate
effectively based on the comparison of the scores from the pre-test
and post-test final scores carried out before and after the
education was given. Providing education to caregivers with
educational video media provides effective results in increasing
caregiver knowledge in this field. The formal caregiver group has
better results than the informal caregiver group at $77.7 \%$ on the
pre-test by formal caregiver and an assessment of 65\% on the pre-
test by informal caregiver. In the post-test assessment, the formal
caregiver got a score of 87.7\% and for the informal caregiver it
was 90\%. There is an increase in the post-test scores of the two
caregiver groups after providing education through video media.

\section{ARTICLE HISTORY}

Received: July 26, 2021

Revised: August 9, 2021

Accepted: August 18, 2021

Published: October 31, 2021

(Online)

doi:

10.20473/jcmphr.v2i2.251331

\section{KEYWORDS}

Presbycusis; hearing loss; effective communication against hearing loss sufferers; empowerment; disease

\section{CORRESPONDING}

AUTHOR

Nyilo Purnami

$\bowtie$ nyilo@fk.unair.ac.id

Department of Ear Nose Throat (ENT) - Head Neck Surgery, Faculty of Medicine, Universitas Airlangga -

Dr. Soetomo General Academic Hospital, Indonesia,

Jl. Mayjend Prof. Dr. Moestopo 4-6, Surabaya, Indonesia

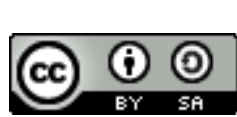

\section{INTRODUCTION}

Presbycusis is a progressive sensorineural hearing loss. These disorders can range from a variety of ages and usually affect hearing loss from a high frequency first. ${ }^{1}$ In general, hearing loss can occur at the age of 65 and there are several factors that influence it. One of the factors that can influence it is cardiovascular disease. $^{2}$
It is estimated that around the world there are $30-45 \%$ of people who are over 65 years old and in Indonesia there are $30-35 \%$ of people aged 65-75 years experiencing presbycusis. ${ }^{3}$ Presbycusis mainly occurs in the male gender. About $40 \%$ of people with presbycusis experience hearing loss by age 65. In the research conducted by Maria Fernanda, it was found that presbycusis that occurred at the age of 65-75 years ranged from $30-35 \%$ and at the age of more than 70 years ranged from $40-50 \% .{ }^{4}$ There is another 
study conducted by Chou, it was found that at the age of more than 65 years, the incidence of presbycusis was $18.9 \%{ }^{5}$ According to WHO in 2005, there were 1.2 billion people aged over 60 years. In Indonesia, from a survey conducted in 7 provinces in 1994 - 1996, it was found that the incidence of presbycusis was $2.6 \%{ }^{6}$

Presbycusis can cause an obstacle, especially in people who are elderly. Communication difficulties due to presbycusis are usually not understood or understood by people with normal hearing function. Therefore, the understanding of presbycusis must be improved so that there is no gap between the caregiver and people with poor hearing. ${ }^{7}$ Some caregiver have been given guidance according to the government to take care of presbycusis patient. $^{8}$

The purpose of this research paper is to provide education to caregivers both informally and formally related to presbycusis. In addition, this study aims to determine and compare the level of knowledge of formal and informal caregivers, especially regarding communication with presbycusis patients.

\section{MATERIALS AND METHODS}

This research uses a descriptive quantitative method. The target is the caregiver, both formal and non-formal, who treats the elderly over 65 years and the elderly who have or are being treated with hearing loss (presbycusis). This research was conducted by presenting an educational video with a duration of less than 5 minutes related to presbycusis, but beforehand the target will be asked to fill out a short questionnaire related to presbycusis knowledge then evaluated with a questionnaire after watching the video, then calculating the understanding level score before and after watching the video. This research was conducted for several days from 3-14 August 2020.

\section{RESULTS}

Education about hearing loss in the elderly was followed by 21 formal caregivers and 16 informal caregivers. A total of 16 formal caregivers conducted a pre-test, participated in video education, and conducted a post-test. Meanwhile, the other 5 formal caregivers only did the pre-test and attended the video education. A total of 12 informal caregivers conducted a pre-test, attended video education, and conducted a post-test. Meanwhile, the other 4 informal caregivers only did the pre-test and attended the video.

Table 1. Percentage of correct answers to each question by formal and informal caregivers

\begin{tabular}{|c|c|c|c|c|c|}
\hline \multirow{2}{*}{ No. } & \multirow{2}{*}{ Question } & \multicolumn{2}{|c|}{ Pre-test } & \multicolumn{2}{|c|}{ Post-test } \\
\hline & & Formal & Informal & Formal & Informa \\
\hline 1. & $\begin{array}{l}\text { What is your position when talking to someone } \\
\text { with a hearing loss? }\end{array}$ & $93.75 \%$ & $83.3 \%$ & $100 \%$ & $100 \%$ \\
\hline 2. & $\begin{array}{l}\text { When talking to people with hearing loss, how } \\
\text { good would it be? }\end{array}$ & $75 \%$ & $50 \%$ & $93.75 \%$ & $83.3 \%$ \\
\hline 3. & $\begin{array}{l}\text { Here are some things to avoid when talking to } \\
\text { someone with a hearing loss, except? }\end{array}$ & $81.25 \%$ & $83.3 \%$ & $87.5 \%$ & $91.6 \%$ \\
\hline 4. & $\begin{array}{l}\text { What should be done if the sufferer does not } \\
\text { understand the speaker's speech? }\end{array}$ & $62.5 \%$ & $41.6 \%$ & $93.75 \%$ & $83.3 \%$ \\
\hline 5. & $\begin{array}{l}\text { What should you pay attention to when you } \\
\text { provide important information (place, time, } \\
\text { phone number, etc.)? }\end{array}$ & $75 \%$ & $58.3 \%$ & $93.75 \%$ & $91.6 \%$ \\
\hline
\end{tabular}

All formal and informal caregivers responded that they understood the flow and procedure of education provided through informed consent before conducting and 
post-test. In the post-test section, a column is also given to provide criticism, suggestions, and assessments regarding the education given.

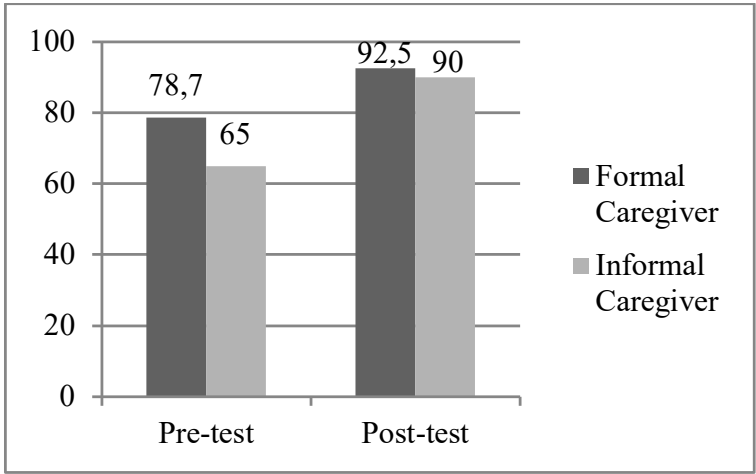

Figure 1. Correct Score Ratio on Pre-test and Posttest $(\%)$

Of the 12 informal caregivers, there were $83.3 \%$ of respondents who answered the first question correctly during the pre-test and increased to $100 \%$ during the post-test. As many as $50 \%$ of respondents answered the second question correctly during the pre-test and this increased to $83.3 \%$ in the post-test.

In the research on effective communication with hearing loss sufferers, a total of 37 respondents took the pre-test and 28 respondents took the post-test. The graph shows the percentage of results that increased in the final post-test score compared to the pre-test in each caregiver group after education was given. The formal caregiver group got a higher final score on the pre-test and post-test than the informal caregiver group.

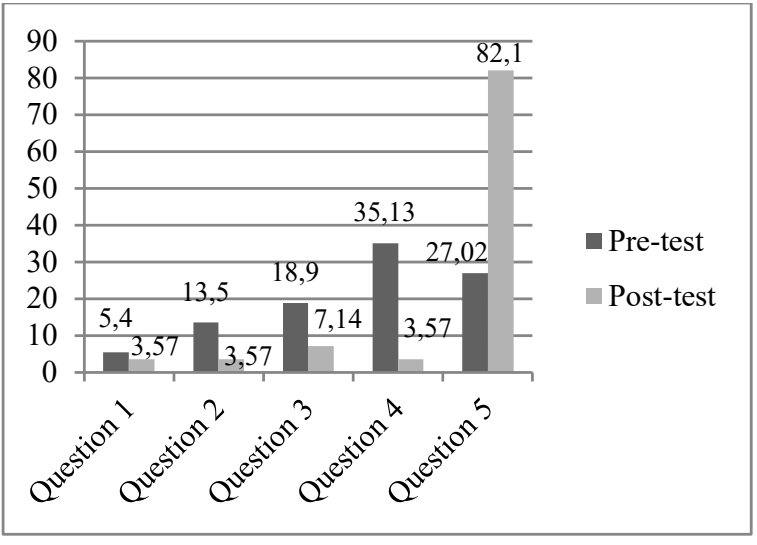

Figure 2. Correct Score Ratio for Each Question on Pre-test and Post-test (\%)

Of the total 37 respondents who had taken the pre-test, only 28 of them took the post-test. It was found that there was an increase in understanding of the material provided, this can be seen from the final assessment score on the pre-test and post-test. In Figure 2, regarding the graph of the general caregiver score percentage pre and post test, it can be seen the comparison of the percentage of the total pre-test and post-test scores, experienced an increase with evidence of an increase in the percentage of the final score. The acquisition score of pre-test to post-test was decrase.

\section{DISCUSSION}

Some caregivers said that education through educational videos was good and informative, but there were some caregivers who gave criticism about the educational videos that the duration was too long, dubbing was too slow, and the video transition was too fast. Besides that, there are also formal caregivers suggesting to give application examples so the educational video it's easier to understand. ${ }^{9}$ All criticism and suggestions given by caregivers in this case are in line with the article entitled effective educational videos. Principles and guidelines for optimizing the student learning process through educational videos, the 
important point is talk about effectiveness of an educational video are keeping the video short, mixing audio and visual for important messages, use an enthusiastic conversational style so that the audience is more interested and involved in the educational video. ${ }^{3}$

After education on how to communicate effectively in hearing loss sufferers using educational videos, there is an increase in the knowledge of each caregiver group about how to communicate effectively based on the results of the pre-test and post-test that were tested before and after intervention. Based on total respondents who took the pre-test, $27.02 \%$ got a score 5 , then increased in the post-test with a percentage score $82.10 \%$ of the total respondents. From the evaluation, it can be seen that most caregivers already know how to communicate effectively with hearing loss sufferers, but there are still many who do not really understand how to communicate effectively. After comparing the pre-test and post-test, there is a significant increase in the general percentage of the final score results. This explained education to each caregiver grup using educational video, providing effective results in increasing the caregiver's knowledge. This is in line with the pilot program that has been carried out in America for veteran caregivers, after intervention by asking the caregiver to read manuals, there was an increase in knowledge measured through pre and post questionnaires. ${ }^{10}$

In general, formal caregivers should have more information about effective communication with hearing loss patients compared to informal caregivers. The data from this study indicate the percentage of pre-test and post-test of the formal caregiver group gets higher final scores. In the pre-test, $78.70 \%$ of formal caregivers answered correctly, while in informal caregivers only $65 \%$ and in the post-test $92.5 \%$ of formal caregivers answered correctly, while in informal caregivers only $90 \%$. This is in line with the theory that more formal caregiver groups understand how to communicate effectively with hearing loss sufferers. From the data that has been obtained, each caregiver group gets an increased final posttest score, this indicates that the education that has been given to caregivers about how to communicate effectively to people with hearing loss has been well received.

\section{CONCLUSION}

There is an effect of educational video interventions on caregiver knowledge about hearing loss in the elderly. This increase varies between formal caregivers and informal caregivers. For a formal caregiver, The pretest score is higher when compared to a formal caregiver. The same as the results of the post-test scores after giving the educational video.

\section{REFERENCES}

1. Lahdji A (2015). Buku Ajar Sistim Telinga, Hidung, Tenggorokan: Fakultas Kedokteran Universitas Muhammadiyah Semarang.

2. Fatmawati R (2016). Karakteristik Penderita Presbiakusis, 1(4). Available at https://www.ncbi.nlm.nih.gov/pmc/articl es/PMC2378751/.

3. Brame CJ (2016). Effective Educational Videos: Principles and Guidelines for Maximing Student Learning from Video Content. Available at https://www.ncbi. nlm.nih.gov/pmc/articles/PMC5132380/ pdf/es6.pdf.

4. Cheslock M, Jesus O (2020). Prebycusis. Available at ncbi.nlm.nih.gov

5. Lee K.Y (2013). Pathophysiology of agerelated hearing loss (peripheral and 
central). Korean J Audiol, 17(2): 45-9

6. Melinda (2012). Faktor yang berpengaruh terhadap kejadian prebikusis di Rumah Sakit Dr. Kariadi Semarang. ORLI, 42(1):45-9

7. Diameta E, Adandom I, Jumbo, et al. (2018). The Burden Experience of Formal and Informal Caregivers of Older Adults with Hip Fracture in Nigeria: SAGE Open Nurs.

8. Kementerian Pertanian RI (2019). Panduan Praktis untuk Caregiver dalam Perawatan Jangka Panjang bagi Lanjut Usia. Available at http://kesga.kemkes. go.id/images/pedomanpanduan $\% 2520 \mathrm{pr}$ aktis\%2520caregive\%25202019.pdf.
9. Mustofa U, Mardiani (2020). Efektifitas Pengguna Media Pembelajaran Video Tutorial untuk Meningkatkan Kompetensi Menggambar 3D. Ef Pengguna Media Pembelajaran Video Tutor untuk Meningkat Kompetensi Menggambar 3D. Available at journal.unnes.ac.id > nju > JPTM > article $>$ download NIH. 2020. Presbycusis.

10. Thomas L (2017). Improving Caregiver Knowledge of Support Resources. Available at https://www.ncbi.nlm.nih. gov/pmc/articles/PMC6370420/pdf/fp34-03-45.pdf 